\title{
Organize Bir Suç Olarak İnsan Ticareti: Arnavutluk Örneği ${ }^{1}$
}

\author{
Furkan YILDIZ \\ Dr. Öğr. Üyesi, Kırklareli Üniversitesi, \\ Sosyal Bilimler Meslek Yüksekokulu, Dış Ticaret Programı \\ yildizfurkan@klu.edu.tr \\ Orcid ID: https://orcid.org/0000-0003-1533-222X
}

\author{
Ali HÜSEYINOĞLU \\ Doç. Dr., Trakya Üniversitesi, \\ Balkan Araştırma Enstitüsü \\ alihuseyinoglu@trakya.edu.tr \\ Orcid ID: https://orcid.org/0000-0002-2101-217X
}

\section{Öz}

İnsan ticareti, uluslararası hukukun ve ülkelerin iç hukuk mekanizmalarının önlem almaya çalıştığı, daha çok suç olarak görülen fakat mağdurlarının çoğu zaman tam manasıyla ihlal edilen haklarını geri alamadığı bir olgudur. Herhangi bir ayrım gözetilmeden her insanın bu suçun mağduru olabileceği gerçeğinin üzerine inşa edilen bu suç, bölgesel talepleri karşılamak için mağdurların belirlenmesinde taleplere yönelik arz oluşturmaktadır. Bu çalışmada, Balkan coğrafyası bağlamında insan ticareti suçu değerlendirilerek bölgesel talepler ortaya konmuş ve dünyanın en aktif göç rotalarından biri olan Batı Balkan Rotası incelenmiştir. Özelde ise hem coğrafi konumu nedeniyle hem de ülke içerisindeki organize suç faaliyetlerinin giderek artması nedeniyle insan ticareti suçuna katılımın dikkat çektiği Arnavutluk incelenmiştir. Bu incelemede, Arnavutluk'un insan ticaretine karşı atmış olduğu hukuki ve politik adımlar değerlendirilmiştir. Hukuki sistemdeki eksiklikler, mağdur sığınma evlerinin ekonomik sorunları, insan ticaretine karşı yürütülen politikaların mağdurları korumaktan ziyade konunun kriminal boyutuna odaklanması gibi eksikliklerin normatif değişimi ve bunların ulusal hukuka yansıtılması analiz edilmiş ve çözüme dair Avrupa Birliği'nin ve Birleşik Devletlerin yayınladığı raporlar incelenmiştir.

Anahtar Kelimeler: İnsan Ticareti, Balkan Rotası, Organize Suçlar, Arnavutluk

\footnotetext{
${ }^{1}$ Makale Geliş/Kabul Tarihi: 18.08.2020 / 15.02.2021

Künye Bilgisi: Yıldız, F. ve Hüseyinoğlu, A. (2021). Organize bir suç olarak insan ticareti: Arnavutluk örneği. Kahramanmaraşs Sütçü İmam Üniversitesi Sosyal Bilimler Dergisi, 18(1), 659-687. DOI: 10.33437/ksusbd.782030
} 


\title{
Trafficking in Human Beings as an Organized Crime: The Case of Albania
}

\begin{abstract}
Human trafficking is a phenomenon in which international law and the domestic law mechanisms of countries try to take precautions, which are seen as a crime, but their victims are often not fully compensated. This crime, built on the fact that every person can be the victim of this crime without any discrimination, constitutes a supply for demands in identifying victims to meet regional demands. In this study, in the context of Balkan geography, human trafficking crime is evaluated, regional demands are revealed and the Western Balkan Route, one of the most active migration routes in the world, is examined. In particular, this research focuses on the case of Albania, which attracts attention to trafficking in crime due to its geographical location and the increasing number of organized crime activities within the country. In this respect, legal and political steps taken by Albania against human trafficking are explored. Deficiencies in the legal system, economic problems of victim shelters, and policies focusing on the criminal aspect of the issue rather than protecting the victims of human trafficking are elaborated through lenses of normative changes and their reflections in national law of Albania. While doing so, reports published by the European Union and the United States regarding the solution are also examined.
\end{abstract}

Keywords: Trafficking in Human Beings, Balkan Route, Organized Crimes, Albania

\section{GÍRIŞ}

İnsan ticareti günümüz dünyasında bölge, cinsiyet, trk ve yaş gibi demografik özellikler konusunda herhangi bir ayrım gözetmeksizin varlığını devam ettiren, kişilerin en temel insan haklarını ihlal ederek bu ihlallerden tacirlere para kazandıran bir ölçü olarak birçok araştırmaya konu olmuş bir suçtur. İnsan ticaretinin, 2000 yılında ortaya konulan tanımı Birleşmiş Milletlerin Sınıraşan Organize Suçlar Sözleşmesinin bir parçası olarak kabul görmüş ve bu bağlamda değerlendirilmiştir. Daha sonraki bölümlerde bahsedilecek olan suçun karakteristik özelliklerinden biri olan suçun çok yönlü ilerlemesinin (hem ülkelerin egemenlik alanlarında hem de sınıraşan nitelikte) bir sebebi olarak konu, uluslararası ilişkiler disiplini adına da önem arz etmektedir. Bunun yanında organize suç kimliği taşıyan bu suçların tarafları birden çok olduğundan, kimi zaman farklı ülkelerden ve bölgelerden kimi zamanda farklı uyruklardan örgütlerin iştirakiyle devletlerin güvenlik algılarına tehdit olarak ortaya çıkması da insan ticareti suçunu uluslararası ilişkiler disiplininde sıkça kullanılan tehdit kavramının altına almaktadır. Bu doğrultuda, Rosenau (1995: 29) bu suçların 
sınıraşan niteliklerini "hükümetler tarafından yürütülen uluslararası ilişkilerin özel bireyler, gruplar ve toplumlar tarafından da, olayların seyri için önemli sonuçları olabilecek ve sonuçları olan ilişkilerle desteklendiği süreçler" olarak tanımlamıştır. Bu noktada bakıldığı zaman Birleşmiş Milletler Şartı madde 2(1)'in ve 2(4)'ün ortaya koyduğu ve devletlerin sahip olduğu üç temel ilke olan "egemenlik, eşitlik ve ülke bütünlüğü̈ konularıyla sınıraşan organize suçların, ülkelerin egemenlik haklarına ve ülke bütünlüklerine tehdit olduğu anlaşılmaktadır.

Milletler Cemiyeti ve Birleşmiş Milletler gibi ulus üstü yapıların kurulmasıyla devletlerin hakim güç olma durumları bir adım geri alınmış ve karar alma mekanizmaları kontrole tabi tutulmuştur. $\mathrm{Bu}$ durum, devletlerin uluslararası ilişkiler için tek aktör olduğuna inanan Realist uluslararası ilişkiler yaklaşımının temelinden sarsılmasına sebebiyet vermiştir (Antunes ve Camisao, 2017). Bu duruma ek olarak, günümüzde de yansımalarını sıkça gördüğümüz, korsanlık, uyuşturucu madde ticareti ve kölelik gibi suçlar aslında tarihte sınıraşan nitelikteki eylemler olarak karşımıza çıkmıştır. Geçen yüzyılda konu ile ilgili olarak devletlerin egemenlik alanlarındaki karar alma süreçlerini değişime sokan adımlar, bu tür suçlara karşı uluslararası bir ceza mekanizması üretilmesiyle başlamıştır (Nadelmann, 2010: 18). Bu doğrultuda, ülkelerin hem egemenlik bölgelerinde hem de söz sahibi olarak varlıklarını ispat etmek istedikleri uluslararası ortamda geçmişten günümüze kadar etkisini gösteren sınıraşan nitelikteki suçlar, oluşturdukları tehditlerde sadece mağdur olan insanları değil aynı zamanda da manevra ve hareket bölgeleri olan devletleri hedef alır nitelikte geliş̧iş̧ir.

Bu suç 2000'li yılların başına kadar tanımlanamamış ve birçok ülke tarafından görmezden gelinmiş bir konudur. Kökenlerini tarihteki kölelik suçuna dayandırılmış olsa bile insan ticaretinin yapısal farklılıkları ve işleyişle alakalı ciddi farklılıkları vardır. Çalışma bahsedilen farklılıkların 1şı̆̆ında insan ticareti konusu ile ilgili olarak terminolojik unsurların sunumuyla başlayarak ilerleyen bölümlerin kavramsal altyapısını sağlayacaktır. Çalışma temelde iki bölümden oluşmaktadır. İlk bölüm çalışmanın odak noktası olan Arnavutluk'un jeopolitik konumundan kaynaklı karşılaştığı göç, insan ticareti ve organize suçlar gibi konuları anlamlandırabilmek ve sağlam bir zeminde değerlendirebilmek için Balkan coğrafyasını ve bu coğrafyanın düzenli ve düzensiz göç akınlarındaki yerini ve organize suçlar bağlamındaki rollerini incelemiştir. Bu bölüm aynı zamanda insan ticareti suçu denilince anlaşılması gereken suçları vurgulanmış ve mağdurların özellikleri üzerinde durmuştur. Çalışmanın ikinci kısmı ise Arnavutluk özelinde insan ticareti suçunu irdelemiştir. $\mathrm{Bu}$ değerlendirme sırasında ilk önce ülkenin insan ticareti konusundaki normatif değişimi incelenmiş ve değişimin hükümet politikalarına yansımaları analiz edilmiştir. Daha sonra ise, Arnavutluk'un insan ticareti ile mücadelesi bir bütün olarak 
değerlendirilip başarıları ve başarısızlıkları ortaya konmuştur. Çalışmanın geneli literatür ağırlıklı iken bu noktada, hem Arnavutluk'un bir siyasi hedef olarak benimsediği Avrupa Birliği üyeliği kapsamında attığı adımlara Birliğin raporlarında verdiği olumlu/olumsuz tepkiler, hem de Arnavutluk'un da incelendiği Birleşik Devletler tarafından yayınlanan y1llık insan ticareti raporundaki ülke ile ilgili bölümler 2002-2020 y1lları arası dönem için analiz edilmiştir. Bu incelemelerin ardından Arnavutluk'un başlıca eksiklikleri ortaya konarak bu eksiklere yönelik etkin ve mağdur merkezli bir insan ticareti ile mücadele sürecinin nasıl işletilebileceğine dair fikirler bahsi geçen raporlar 1şı̆̆ında oluşturulmuştur.

Çalışma, son dönemde Suriyeli mültecilerden kaynaklı Avrupa'ya olan mülteci akını ile ilişkili olarak Balkanlar'da atılan adımlardan ziyade, Arnavutluk özelinde bir inceleme yapmıştır. Bunun nedeni Arnavutluk'ta ve Avrupa'daki Arnavutlar arasında hızla yayılan organize suçlar ile artan ilişkinin daha net bir şekilde ortaya konabilmesini sağlamaktır. Öyle ki, sınıraşan organize suçlar arasında sayılan insan ticareti uyuşturucu ticareti, silah ticareti, mülke yönelik suçlar ve tütün kaçakçılığı gibi suçlar ile anılan Arnavutluk için bu gibi yasa dışı faaliyetleri destekler durumdadır. $\mathrm{Bu}$ bağlamda çalışma, genel anlamda Arnavutluk'un organize suçlar ile olan ilişkisini ele almayı özelde de insan ticareti ile ilgili atılmış adımlarını değerlendirmeyi amaçlamaktadır.

\section{INSAN TİCARETİ VE BALKAN COĞRAFYASI ILE ILGILI KAVRAMSAL ÇERÇEVE}

Çalışmanın bu bölümünde insan ticareti suçunun ve Balkan coğrafyasının bu çalışma için anlamına bakılarak, bu iki kavramın çalışmanın sınırlarını hangi ölçüde belirlediği incelenecektir. Bu bağlamda, ilerleyiş için bir haritalama yapılacak olursak, ilk önce konunun tarihsel altyapısına değinmeden "insan ticareti" kavramı tanımlanacak ve sonrasında ise "Balkan Coğrafyası" dediğimiz vakit hangi ülkelerin ne ölçüde bu coğrafi yapının içinde olduğu incelecektir. Bir sonraki bölümde bahsi geçen suç için oluşturulan geçiş rotası bağlamında bu coğrafyanın avantajları ve dezavantajları üzerinde durulacaktır.

\section{İnsan Ticareti: Suçlular ve Mağdurlar}

İnsan ticareti suçuna iliş̧in tanımlamanın yirmi yıllık bir geçmişi olsa bile kölelik suçu ile olan benzerlikleri bu suçu aslında aşina olunan fakat uzun bir süre kavramsallaştırılamamış bir suç haline getirmiştir. Literatürde, insan ticareti suçu bir insan hakları ihlali olarak geçmesine rağmen, insan hakları ile ilgili uluslararası hukuk normları içinde ele alınmamış olan bu konu, sınıraşan organize suçların biri olarak karşımıza çıkmaktadır. 2000 yılından sonra normatif bir çerçeveye kavuşan insan ticareti suçu, hem genel geçer bir tanıma kavuşmuş hem 
de devletlerin bu suçla ilgi mücadele yöntemlerinin oluşmasıyla aktif olması beklenen bir mekanizma ile düzenlenmiştir.

Sınıraşan organize suçlar konseptinin içerisinde değerlendirilen insan ticareti, 15 Kasım 2000 yılında Birleşmiş Milletler Genel Kurulu 55/25 sayılı kararı vasitasıyla kabul edilen ve 19 Eylül 2003 yılında 147 üye devletin imzasıyla yürürlüğe giren, Sınıraşan Örgütlü Suçlara Karşı Birleşmiş Milletler Sözleşmesine Ek İnsan Ticaretinin Özellikle Kadın ve Çocuk Ticaretinin Önlenmesine, Durdurulmasına ve Cezalandırılmasına ilişkin Protokol (İnsan Ticareti Protokolü) ile uluslararası bir tanıma kavuşmuştur. Diğer bir değişle, insan ticareti, 2000 yılındaki İnsan Ticareti Protokolü’ne kadar ne olduğuna dair üzerinde fikir birliği sağlanamamış olan bir suçtu. Protokol madde 3(a) bu suçu şu şekilde tanımlanmıştı;; "İnsan ticareti, kuvvet kullanarak veya kuvvet kullanma tehdidi ile veya diğer bir biçimde zorlama, kaçırma, hile, aldatma, nüfuzu kötüye kullanma kişinin çaresizliğinden yararlanma veya başkası üzerinde denetim yetkisi olan kişilerin rızasını kazanmak için o kişiye veya başkalarına kazanç veya çıkar sağlama yoluyla kişilerin istismar amaçlı temini, bir yerden bir yere taşınması, devredilmesi, barındırılması veya teslim alınması anlamına gelir. İstismar terimi, asgari olarak, başkalarının fuhuşunun istismar edilmesini veya cinsel istismarın başka biçimlerini, zorla çalıştırmayı veya hizmet ettirmeyi, esareti veya esaret benzeri uygulamaları, kulluğu veya organların alınmasını içerecektir.” (İnsan Ticaretinin, Özellikle Kadın ve Çocuk Ticaretinin Önlenmesi, Ortadan Kaldırılması ve Cezalandırılmasına İlişkin Protokol, 2003).

İnsan ticareti suçunun bu tanımı, Avrupa Birliği ve Avrupa Konseyi gibi uluslararası örgütlerin ve bunların yanında birçok uluslararası sivil toplum kuruluşu ve uluslararası birliğin insan ticaretine karşı yürüttükleri mücadelede temel yol haritası olmuştur. Ayrıca, Protokolün bir gerekliliği olarak, taraf devletlerin bu suçu cezalandırmakta kullanacağı iç hukuk enstrümanı haline gelmiştir. İnsan ticareti suçunun bir insan hakları ihlali olarak görülse bile konunun bir diğer boyutu da bu suçun bir ticari iş olarak görülmesidir. Konu ile ilgili olarak INTERPOL'ün yaptığ 1 değerlendirmeye göre, insan ticareti, modern bir kölelik mekanizması kuran ve milyarlarca dolarlık bir hacme sahip uluslararası organize bir suç formudur (Interpol, 2019).

Amerika Birleşik Devletleri tarafından 2020 yılında yayınlanan İnsan Ticareti Raporu, insan ticareti suçu ile ilgili olarak en güncel verileri göz önüne sermiştir (U.S. Department of States, 2020). Bu rapora göre, 25 milyon insan, bu suç nedeniyle özgürlüklerinden ve temel insan haklarından mahrum bırakılmıştır. Bahsi geçen bu hacim yıldan yıla artarak büyümekte ve kurbanlarının sayısını her geçen gün arttırmaktadır. Bu duruma kaynak gösterilecek olduğunda, 2006 İnsan Ticareti Raporu o dönem için tahmini insan ticareti kurban sayısını 12,3 milyon 
olarak vermişti (U.S. Department of States, 2006). Aradan geçen 13 y1lın ardından kurbanların sayısı neredeyse iki kat arttığının altı çizilmelidir.

Tablo 1. BMUSO Tarafindan 2009, 2012, 2014, 2016 ve 2018 Yillarında Yayınlanan İnsan Ticareti Küresel Raporlarının Derlemesi

\begin{tabular}{|c|c|c|c|c|}
\hline Yıl & Kadın & Erkek & Kız Çocuk & $\begin{array}{c}\text { Erkek } \\
\text { Çocuk }\end{array}$ \\
\hline $\mathbf{2 0 0 6}$ & $\% 66$ & $\% 12$ & $\% 13$ & $\% 9$ \\
\hline $\mathbf{2 0 0 9}$ & $\% 59$ & $\% 14$ & $\% 17$ & $\% 10$ \\
\hline $\mathbf{2 0 1 1}$ & $\% 49$ & $\% 18$ & $\% 21$ & $\% 12$ \\
\hline $\mathbf{2 0 1 4}$ & $\% 51$ & $\% 21$ & $\% 20$ & $\% 8$ \\
\hline $\mathbf{2 0 1 6}$ & $\% 49$ & $\% 21$ & $\% 23$ & $\% 7$ \\
\hline
\end{tabular}

(UNODC, 2009: 11; UNODC, 2012: 10; UNODC, 2014: 5; UNODC, 2017: 7; UNODC, 2018: 10).

Bu süreçte, insan tacirleri, kadın, erkek, yaşlı veya çocuk ayrımı gütmeden doğan taleplere cevap vermek için her yaş grubundan ve her cinsiyetten kurbana ulaşmaktadır. Konu ile ilgili olarak BMUSO de insan ticaretinin ağır bir suç ve insan hakları ihlali olduğunun altını çizmiştir (UNODC, 2011: 3). Bu suçun her hangi bir ahlaki kodu veya etik yaklaşımı yoktur, asıl olan piyasada ki talebi karşılamak ve kar elde etmektir. Bu bağlamda, bu suçun her hangi bir yaş veya cinsiyet kriteri olmadığının altı çizilmelidir (D’Cunha, 2002: 2). Yukarıdaki tablodan da anlaşlabileceği gibi, insan ticaretinin küresel boyutta incelenmesi durumunda kadınların daha büyük bir oranda kurban oldukları dikkat çekmektedir.

Tablo 2. BMUSO’nin Raporlarının Verilerinin Yaş Faktöründen Arındırılmış Hali

\begin{tabular}{|c|c|c|}
\hline Yıl & Kadın & Erkek \\
\hline $\mathbf{2 0 0 6}$ & $\% 79$ & $\% 21$ \\
\hline $\mathbf{2 0 0 9}$ & $\% 76$ & $\% 24$ \\
\hline $\mathbf{2 0 1 1}$ & $\% 70$ & $\% 30$ \\
\hline $\mathbf{2 0 1 4}$ & $\% 71$ & $\% 29$ \\
\hline $\mathbf{2 0 1 6}$ & $\% 72$ & $\% 28$ \\
\hline
\end{tabular}

. (UNODC, 2009: 11; UNODC, 2012: 10; UNODC, 2014: 5; UNODC, 2017: 7; UNODC, 2018: 10).

Yaş ayrımına gitmeksizin kurbanları incelediğimizde ise karşımıza çıkan sonuç BMUSO'nin küresel raporlarında her yaş grubundan kadın mağdurların beş rapor döneminde ki yüzdelik oranlarının \%70-\%80 bandında seyrettiği görülmektedir. 
$\mathrm{Bu}$ tablolardaki gerçeklikler, 1990'ların başında Sovyetler Birliği'nin dağılmasının ardından ortaya çıkan resimle daha da gündeme gelmiş ve uluslararası toplumun insan ticareti konusunda endişeleri arttırmıştır. $\mathrm{Bu}$ bağlamda, uluslararası hukukun kölelik ve kölelik benzeri uygulamalar için atmış olduğu adımlar yetersiz kalmış ve bu suça yönelik normatif bir yaklaşım benimsenmesi beklenir hale gelmiştir. Uluslararası toplumun bu beklentisini arttıran Sovyetlerin dağılmasından başka birçok tetikleyici etken vardır. Örnek olarak, Latin Amerika ve Asya da ciddi oranda artan çocuklara yönelik cinsel istismar konularının gündeme gelmesi verilebilir (Thomas v.d., 1993: 123). Buna ek olarak, küresel anlamda kadınların ve çocukların seks endüstrisinde çalıştırılması ve birçok kadının ev işlerini yapması için insan ticaretine konu edilmesi giderek artmaya başlayan eğilimler olarak ortaya çıkmıştır (O’Neill, 2000: 3). Uluslararası Göç Örgütü’nün verilerine göre yıllık 500 bin kadın ve çocuk Avrupa'ya insan ticareti vasitasıyla getirilmektedir (IOM, 1998). Sadece Güney Asya da aylık 500 Bangladeşli kadın yasa dışı yollarla Pakistan'a sokulmaktadır; yılda 150 bin Filipinli kadın Japonya'ya yasa dışı yollarla sokulmaktadır; yıllık 7000 Nepalli kadın ve kız çocuğu da Hindistan da ki genel evlere satılmaktadır (CATW-Asia Pacific, 1996; Centre for Women and Children Studies, 1997: 33). Brezilya, Venezüella ve Kolombiya da küçük kızlar kaçırılarak genel evlere ve madenlere satılmıştır (Daguno, 1998: 2). Tüm bunlara ek olarak, İtalyan Kamarro, Çin Triadları, Rus Mafyası ve Japon Yakuzalar da kadınları ve kız çocuklarını cinsel sömürü aracı olarak kullanarak suç gelirlerini arttırmışlardır (Raymond, 2002: 493). Böylece, küresel anlamda erkekler, kadınların ve çocukların, bölgesel, ulusal veya yerel anlamda insan ticaretine konu edildikleri görülmektedir (Limoncelli, 2009: 78).

\section{Balkan Coğrafyası ve Organize Suçlar}

Balkan coğrafyası, sınırları konusunda büyük ölçüde fikir birliğine varılsa bile halen yarım adanın kuzey sınırları üzerine tartışmaların sürdüğü bir bölgedir (Danforth v.d., 2016). Topraklarının tamamı Balkanlar'ın sınırları içinde ülkeler olan Arnavutluk, Bosna-Hersek, Bulgaristan, Karadağ, Makedonya Cumhuriyeti, Yunanistan ve Kosova olarak sayılmaktadır. Bir de topraklarının büyük kısmı Balkanlarda olan ve Balkan ülkesi sayılan Sırbistan, Hırvatistan, Slovenya ve Romanya bu coğrafyanın birer parçasıdır. Buna Türkiye'nin Trakya Bölgesi de eklendiğinde, Balkan coğrafyası 12 devleti sınırlarının içerisine alan bir bölge olarak karşımıza çıkmaktadır (Danforth vd., 2016). Çalışmanın zemin olarak kullanacağı Balkanların, coğrafyası hakkındaki bu temel haritanın ardından çalışmanın ilerleyen kısımlarında sıkça kullanılacak olan organize suçlar konusunun da genel hatlarını çizerek bu bölgede ki organize suç faaliyetlerine değinmekte fayda vardır. 
1990'lar küresel siyaset için hızlı ve çalkantılı dönemler olarak tarihte yer etmiştir. Sovyetler Birliği'nin ve Yugoslavya'nın dağılmasının ardından ortaya çıkan devletler bahsi geçen dönemde ki siyasi istikrarsılılkları, savaşları ve etnik kıyımları Birleşmiş Milletlerin (BM) gündemine getiren yeni üyeler haline gelmişlerdir. $\mathrm{Bu}$ dönem aynı zamanda organize suçların da $\mathrm{BM}$ gündemine girdiği dönemdir (Felsen ve Kalaitzidis, 2005: 14). Nitekim BM'nin 50. kuruluş yılında, Birleşik Devletler Başkanı Bill Clinton, BM'yi sınıraşan suçlarla ilgili işbirliği konusunda teşvik etmiş ve 1996 yılında Birleşik Devletler sınıraşan organize suçları kendi ulusal güvenlik konularının başına taşımışıtır (Lupsha, 1995; Vlasis, 2002: 27). 1997 yılında BM, sınıraşan organize suçlar ile ilgili bir sözleşme taslağı üzerinde çalışmalarına başlamış ve nihayetinde $15 \mathrm{Kasım}$ 2000'de Birleşmiş Milletler Sınıraşan Organize Suçlar Sözleşmesini ve üç ek Protokol Genel Kurul da kabul edilmiş ve konunun hassasiyeti ile ilgili ilk uluslararası adımı atmıştır.

Sözleşme, suç olarak sayma, uluslararası işbirliği, teknik destek ve uygulama konularının altını çizerek, sınıraşan organize suçlar bağlamında ilk uluslararası çerçeveyi oluşturmuştur (Vlasis, 2002). Sözleşme, "organize suç" oluşturan durumlarla üç tutum çerçevesinde baş etmeye çalışmıştır. Sözleşme m.2 (a-c) bahsi geçen üç tutumu şu şekilde tanımlamıştır (Sınıraşan Örgütlü Suçlara Karş1 Birleşmiş Milletler Sözleşmesi, 2003):

a) "Organize suç örgütü” kavramını, doğrudan veya dolaylı olarak mali veya diğer bir maddi çıkar elde etmek amacıyla belli bir süreden beri var olan ve bu Sözleşmede belirtilen bir veya daha fazla ağır suç veya yasadışı eylemi gerçekleştirmek amaciyla birlikte hareket eden, üç veya daha fazla kişiden oluşan yapılanmış bir grup olarak tanımlamıştır.

b) "Ağır suç", dört yıl veya daha fazla hürriyetten mahrumiyeti veya daha ağır bir cezayı gerektiren bir suçu oluşturan davranış olarak belirtilmiştir.

c) "Yapılanmış grup" belirli bir suçu derhal işlemek için tesadüfi olarak oluşturulmamış ve üyelerinin rollerinin şeklen belirlenmesi şartı olmayan, üyeliğinin devamlılığ veya gelişmiş bir yapısı olması gerekmeyen bir grup olarak ifade edilmiştir.

Bu maddedeki unsurlar ile hedef bölgemiz olan Balkanları birleştirdiğimizde ise 1997 yılına kadar üst düzey suç faaliyetlerine yatırım yapabilmek için sermayesi olmayan ve çevresel aktörlerin içerisinde bulunduğu bir suç yapılanması görülmekte iken, günümüzde tüm Avrupa'da aktif ve üst düzey suçları işleyen gruplar karşımıza çıkmaktadır (Arsovska, 2019: 199).

Organize suçlarla Balkan coğrafyasının ilişkisinin temelinde tarihsel olarak kaçakçılık ve eşkıyalık bulunmaktadır (Binder, 2002). Afganistan'ın 
haşhaşlarının Güneydoğu Avrupa'ya sokulması başlarda Türk kaçakçıların başlattığ 1 bir süreç olsa da 1989 yılında Komünist rejimin çöküşünün ardından tüm coğrafya kanunsuzluğa açık hale gelmiştir (Arsovska, 2019: 199). 2000’li yılların başlarına kadar Balkan organize suç faaliyetleri taşeronluk şeklinde yürümekteydi. Temel faaliyet alanları gasp, adam kaçırma, fuhuş, soygun ve koruma şantajı şeklinde sınıflandırılmıştır. İtalyan organize suç örgütleri tarafindan fuhşun kontrolünün Arnavut gruplara verilmesi, uyuşturucu kuryeliğinin yine İtalyan ve Türk organize suç şebekeleri tarafindan Balkan kökenli suçlulara verilmesi şeklinde hareketlenen bu suçlar, özellikle Kosova savaş1 (1998-1999) ve Arnavutluk'ta ki ekonomik sistemin çöküşü (1997) ile Balkan suç örgütleri bireysel olarak güç kazanmaya başlamışlardır (Arsovska, 2019: 199).

2000'li yıllarda değişen organize suç kimliklerine geçmeden evvel, Soğuk Savaş sonrası dönemde Balkan halklarını organize suç faaliyetlerine iten sebeplere bakmakta fayda vardır. Yugoslavya'daki liberalizm etkileri, bölgedeki diğer diktatörlükle yönetilen Romanya ve Bulgaristan gibi ülkelere göre daha özgür ve daha rahat insan ve mal hareketliliği şeklinde kendini göstermekteydi. $\mathrm{Bu}$ durum, bölgenin coğrafi konumunun da avantajıyla Avrupa'ya veya Avrupa'dan çeşitli malların ticareti ve kaçakçıllı̆ı anlamına gelmekteydi (Krasniqi, 2016: 209). Organize suç faaliyetlerine katılım, Kommünist devlet anlayışının çöktüğ̈̈ dönemde ortaya çıkan ekonomik krizler, merkezi otoritede doğan boşluklar nedeniyle ortaya çıkan yolsuzluklar, Yugoslavya'ya uygulanan ekonomik yaptırımlar ve silah ambargoları Avrupa için geçiş konumundaki Balkan coğrafyasında insanların hayatlarını devam ettirebilmek için kullandıkları bir yöntem haline gelmişti (Avrupa Konseyi, 2006; Krasniqi, 2016: 2209-2211; Lotspeich, 1995: 564-567). Bu tetikleyici sebeplerden ötürü organize suç faaliyetleri Balkanlar da hareket alanı bulmuş ve 20.yy'ın son on yıl1, 2000'li yıllarda adından söz ettirecek Balkan organize suç örgütlerinin acemiliklerini attıkları bir dönem olarak yaşanmıştır.

2000'li y1llara gelindiğinde ise Balkan organize suç örgütleri daha önce elde ettikleri deneyimleri bireysel olarak kullanarak Avrupa'da ve hatta dünyada adından sıkça bahsettirecek konuma gelmişlerdir (Arsovska ve Basha, 2013). Bu durumun sebebi olarak bölgeden Avrupa'ya ve Birleşik Devletlere olan göç akını gösterilmektedir (UNODC, 2008: 45). Soğuk Savaş sonrasında vasıfsız ya da yarı vasıflı işgücüne olan talep bu göçleri tetiklemiştir. Öyle ki, tahminlere göre 19892001 yılları arasında 700 binin üzerinde çoğunluğu İtalya'ya ve Yunanistan'a olmak üzere göçmen Arnavutluk'tan ayrılmıştır (Instant Albania, 2005). 19922002 yılları arasında 800 bin civarında Romanya vatandaş1 da Batı Avrupa Ülkelerine, Birleşik Devletlere ve Kanada'ya göç etmiştir (UNHRC, 2007). Bu göçlerin neticesinde hali hazırda vasıfsız ya da yarı vasıflı olan insanlar beklentilerini tam olarak karşılayamamış ve kimisi yasadışı işlere bulaşmıştır. 
2000'li yılların başlarında Balkanlarda ki organize suç eğilimleri üç yasadışı ticaret üzerine yoğunlaşmıştır. UNODC'nin raporuna göre bunlar, uyuşturucu ticareti, insan ticareti ve göçmen kaçakçılığıdır (UNODC, 2008). Avrupa Konseyi'nin Balkanlarda ki organize suç eğilimleri üzerine yürüttüğü çalışmada çıkan sonuç bu ülkelerin organize suç konusundaki yüksek eğilimlerini göz önüne sermektedir.

Tablo 3. 2003 Yılında Her 100 Bin İnsan İçin Organize Suç Bağlantılı Kişi Sayıs1 (Avrupa Konseyi, 2004)

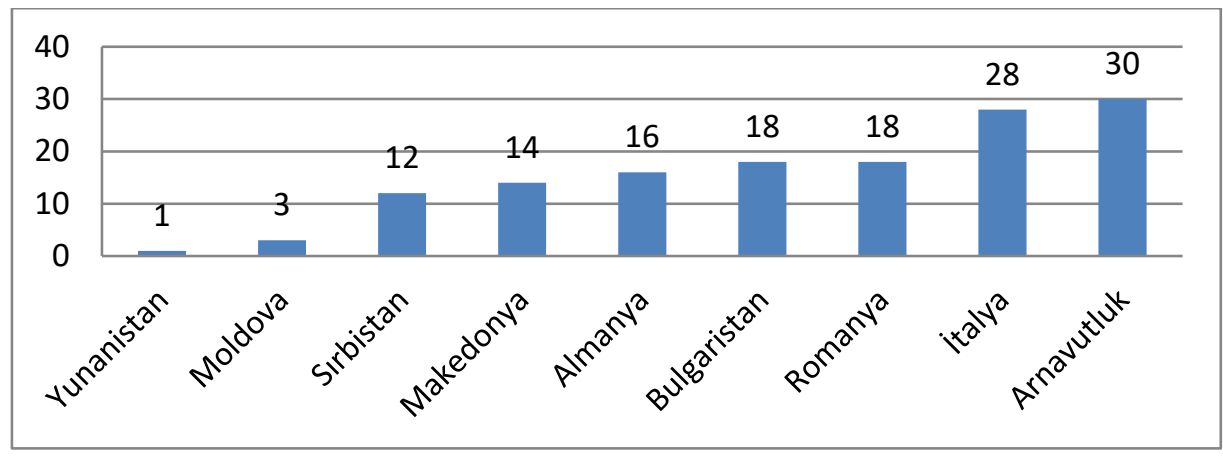

Başta kısaca değinilmiş olan Balkan coğrafyasının konumu organize suç örgütlerini yasadışı ticaret yürütmek konusunda cezbetmektedir. Bu durumun sebebi ise bu coğrafyanın dünyanın en büyük eroin üreticisi olan Afganistan ile dünyanın en büyük eroin tüketiminin olduğu Batı Avrupa arasında bir geçiş konumunda olmasıdır. Bunun yanı sira Balkanlar, Orta Doğu'dan ve Kuzey Afrika'dan insanlara (yasadışı göç ve insan ticareti) Avrupa'ya bir geçiş imkanı sunmaktadır. Nitekim coğrafyanın bu karakteristik özellikleri sadece 2000'lerin başlarında değil, günümüzde de çekici özelliğini sürdürmektedir (Global Initiative against Transnational Organized Crime, 2017: 1).

Balkanlar'ın organize suç örgütlerinin hedefi konumunda olmasını günümüz şartları ile değerlendirilecek olursak, Balkanlar'ın doğu ile batı, kuzey ile güney arasında bir kavşak konumunda olması organize suç örgütleri için önemli bir artıdır. Buna ek olarak, zayıf sınır koruma mekanizmaları, yolsuzluk, bölgedeki çatışma mirası, jeostratejik rekabet, Komünizm sonrası özelleştirme politikaları, Balkanları organize suçlar için açı hedef haline getirmiştir (Global Initiative against Transnational Organized Crime, 2017: 5). Balkanlar, organize suç örgütlerinin kullandığ 1 ve dünya üzerindeki önemli organize suç rotalarından biri olan "Balkan Rotasına" isim veren bölge olarak karşımıza çıkmaktadır.

"Balkan rotası", içerisinde hem karadan hem de denizden yol alınabilen Orta Doğu'dan veya Asya'dan gelen göçmenlerin Avrupa Birliği'ne uzanan yollarını 
ifade eder. Bu rota Türkiye'yi ve Güneydoğu Avrupa'yı kapsamaktadır. Bu rota kimi zaman deniz yolu ile Türkiye ve Yunanistan kullanılarak aktif edilmiş, kimi zaman da kara yolu ile Makedonya'ya veya Bulgaristan'a yönlenerek Sirbistan ve Macaristan yolunu takip ederek ya da Sirbistan, Hirvatistan ve Slovenya yolunu takip ederek Avrupa Birliği'ne ulaşmayı hedeflemiştir (Bechev, 2016). Balkan rotası coğrafi konumunun sağladığı çekici özellikler nedeniyle önemli bir yerdedir. Özellikle son dönemde mülteci kriziyle ön plana çıkan bu güzergah daha önce de belirtildiği gibi uyuşturucu, silah ve insan (insan ticareti ve göçmen kaçakçılığı) unsurları içeren organize suçlarda Avrupa'ya açılan bir kapı konumunda işlev görmektedir. Bu bölümde, Balkan rotasının kapasitesi ve uzandığı bölgeler değerlendirilerek daha sonraki bölümlerin temel konusu olan insan ticareti bağlamındaki rollerinin genel hatları çizilecektir.

Harita 1. Balkan Rotas1

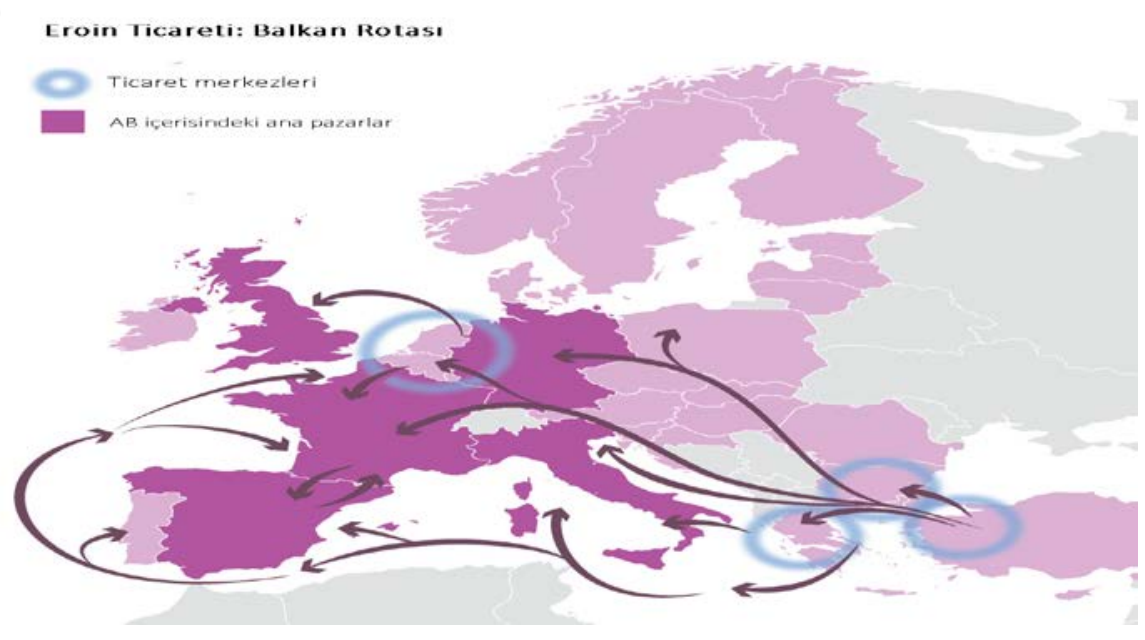

Kaynak: Europol, 2019:117

Afganistan eroini Türkiye üzerinden Batı Balkan ülkeleri vasıtasıyla Avrupa Birliği sınırlarından içeri girmektedir (Yıldız ve Dikmen Yıldız, 2020). Haritada da açık bir şekilde görüldüğü üzere eroin ticareti için en iyi bilinen ve kullanılan rotadır. Burada, eroin Makedonya'ya ve Sırbistan'a ulaşmadan önce Türkiye'den Yunanistan'a ve/veya Bulgaristan'a sokulmaktadır. Buradan da eroin, Avrupa Merkez Rotas1 olarak bilinen Macaristan'1, Slovakya'y1, Avusturya'y1 ve İsviçre'yi içine alan bölgeye ulaştırılır. Bu yola alternatif olarak, eroin, Makedonya'yı ve Kosova'yı kullanarak İtalya'ya ulaştırılmaktadır. Sırbistan'dan ve Karadağ 'dan da eroin Bosna Hersek'e ulaştırılıp Hırvatistan'a ve Slovenya'ya gönderilmektedir (Gibbons, 2015). Balkanlar uyuşturucu ticareti bağlamında incelendiğinde sadece ticari bir güzergah olmaktan çok daha fazladır. Bunun 
nedeni ise ham halde gelen uyuşturucuların bir kısmı Balkanlarda işlenmektedir (Global Initiative Against Transnational Organized Crime, 2019: 4).

Balkan rotası uyuşturucu ticaretinin Avrupa'ya açılan kapı olarak kullanımı kadar yoğun, bir şekilde konusu insan olan göçmen ticareti, insan kaçakçılığ 1 gibi yasa dışı işler için de kullanıldığı bilinmektedir. Özellikle, 2011 yılında ortaya çıkan Suriye İç Savaşı'nın ardından ortaya çıkan mülteci akını ve hali hazırda varlığını hep sürdüren insan ticareti için bu rota, Avrupa'nın anahtarı konumunda değerlendirilmektedir.

Harita 2. Mülteciler İçin Balkan Rotası

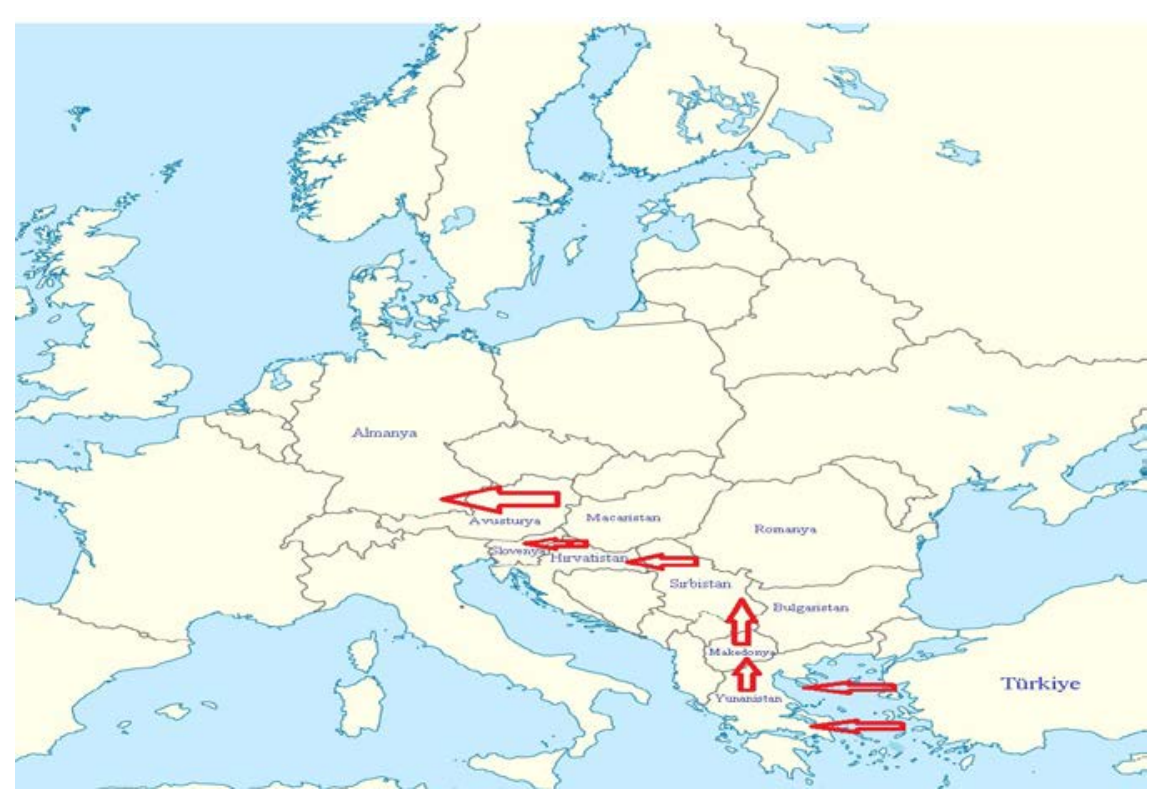

2015 yılında ortaya çıkan ve Avrupa'yı ciddi şekilde etkileyen "mülteci krizi”, aslında Balkan rotasını daha görünür hale getirmiştir. Çoğunluğunu Suriye'den, Irak’tan, Afganistan'dan ve Pakistan'dan gelen mülteci ve göçmenlerin oluşturduğu bu kriz (Brunovskis ve Surtees, 2019: 75), Kuzey Avrupa'ya geçmeye çalışan Kuzey ve Orta Afrika kökenli göçmenlerin de bu yolu kullanması ile kötü bir üne kavuşmuştur ("Balkans Route”, 2017). Bunun sebebi ise uyuşturucu ve silah ticaretinde ön planda olan bu rotanın göçmenleri "uyuşturucudan daha değerli” görmeye başlamasından ötürüdür (Sironi, 2014). Öyle ki, 2009 yılından 2014 yılının sonuna kadar Balkan rotasını kullanarak yasa dış1 bir şekilde Avrupa'ya giren kişi sayısı 80 bini geçmemişken, 2015 yılının başından 2018 yılının sonuna kadar olan dönemde 910 binin üzerine çıkmıştır (Frontex, 2018). Bu artışın sebebi ise Arap Baharı'nın Orta Doğu'da ve Kuzey Afrika'da oluşturmuş olduğu güvensizlik ortamındandır. Göçmenler, Akdeniz’i 
kullanarak Yunanistan ve İtalya üzerinden kendi güvenliklerini sağlayabilmek için Avrupa'ya yönelmişlerdir (Balcı ve Göcen, 2018: 20). Bu yönelimin günümüze kadar yansıyan özellikle 2020 yılının başından bu yana Avrupa'yı etkisi altına alan ve göçmen karşıtı kutuplaşmayı arttıran ciddi bir sonucu da ortaya çıkmış ve 2015 yılından bugüne Avrupa'yı önemli ölçüde etkileyen krizi tekrar canlandırmıştır.

\section{ARNAVUTLUK VE INSAN TICARETİ}

Çalışmanın bu bölümünde, Balkanlarda etkili olan bir organize suç faaliyeti olan insan ticareti konusu Arnavutluk bağlamında ele alınacaktır. Burada hem Arnavutluk'un neden insan ticareti konusunda önemli bir yeri olduğu, hem de hükümetlerin insan ticaretine karşı atmış oldukları adımlar değerlendirilecektir. $\mathrm{Bu}$ temel konulardan önce 2015 y1lında neredeyse tüm Balkanlar'1 ve Avrupa'y1 etkileyen göçmen krizinin, Arnavutluk'u nasıl etkilediğine bakmakta fayda vardır. Bu bakış açısı sıkça birbirine karıştırılan göçmen kaçakçılığ ticaretine ilişkin geliştirilen refleksleri anlamak açısından da yarar sağlayacaktır.

Arnavutluk, Balkan rotasının etkisizleşmesi ile Arnavutluk, Karadağ ve Bosna üzerinden kurulan ve Batı Avrupa'ya ulaşım için yeni bir yol haline gelen güzergahın oluşması ile göçmen krizinden şekilde etkilenmiştir (Bregu, 2019: 68). Bu yeni yol üzerinde Arnavutluk, Avrupa'ya ulaşmak için kullanılan transit ülke konumundadır. Bu bağlamda, Arnavutluk Mülteciler Yüksek Komiserliği Temsilcisi Pablo Zapata ülkenin konumunu, "mülteciler aile bağlarının olduğu Kuzey Avrupa'ya geçmek için yolculuklarına başlamışlar ve Arnavutluk'u göçmen kaçakçıları ile irtibata geçip kuzeye ulaşmak için bir ara durak olarak görmektedirler" ifadeleri ile özetlemişlerdir (Arapi, 2017). Hedef ülkelere ulaşım açısından Arnavutluk'ta iltica talep eden mülteciler ülkede kalmak için değil, büyük ölçüde geçiş sürecini uzatmak maksadıyla bu talepte bulunmuşlardır (UNHCR, 2019: 2). Arnavutluk, Avrupa Birliği dışında olup Avrupa'nın sınır güvenliği için görevlendirmeler yaparak ve araç tahsis ederek sınır geçişleriyle ilgili suçları önlemeye yönelik kendi operasyonunu başlatan ilk ülke konumundadır. $\mathrm{Bu}$ doğrultuda başlatılan ilk görev, 2019 yılı içerisinde Arnavutluk ve Yunanistan kara sınırında geçiş belgelerinin kontrolünü, göçe ilişkin hareketlilikleri, suç içeren faaliyetleri ve insan ticaretini denetlemeyi hedeflemiştir (Frontex, 2019). Konum itibariyle hassas bir noktada olan ve Avrupa geçişleri için bir kapı olarak algılanan Arnavutluk, son dönemdeki göçmen akımı ile değil, aynı zamanda ülkede ve bölgede faaliyet gösteren organize suç örgütlerinin bir diğer gelir kapısı konumundaki insan ticareti ile olan bağıyla da anılmaktadır.

İnsan ticareti suçunda asıl olan insanların istismar edilmesi ve sömürülmesi aracılığıyla kar elde etmektir. Bu bağlamda Balkanlar'da Arnavutluk hassas bir 
noktaya sahiptir. Arnavutluk 2000 yılından 2010 yılına kadar fuhuş istismarı, cinsel sömürü, zorla çalıştırma ve organ ticareti başta olmak üzere insan ticaretine konu olan neredeyse tüm suçlar için mağdur edilen insanların getirildiği bir ülke konumundaydı (Dottridge ve Machel, 2004: 60). Öyle ki, bahsi geçen 10 yıllık dönemde 5000'den fazla kadın, cinsel istismar amaciyla insan ticaretine konu edilmiştir (Balidemaj, 2019: 1304). Yıllar içerisinde tespit edilen mağdur sayısında bir dalgalanma olsa da 2017 y1lında tespit edilen 109 insan ticareti mağdurunun içerisinde kadın ve kız çocuklarının oranı \%80'e ulaşmıştır (U.S. Department of States, 2019: 62). Arnavutluk'un transit ve konak ülke olarak görülmesinden ziyade, aynı zamanda bir kaynak ülke konumunda da değerlendirilmiştir. Avrupa'da 2015-2016 yılları arasında insan ticareti olarak kayda geçirilen 10372 mağdurun 1397'si Arnavutluk vatandaşıdır (U.S. Department of States, 2019: 63). Bu oran genele bakıldığında \%10'luk bir dilimin üzerindedir.

\section{İnsan Ticareti ile İlgili Arnavutluk'un Hukuki ve İdari Uygulamaları}

Arnavutluk, geçiş rotası olarak kullanıldığından, Batı Avrupa'ya bir giriş kapısı olarak görüldüğ̈̈nden ve ayrıca son dönemde de Avrupa'da güçlenen Arnavutluk menşeili organize suç örgütleri nedeniyle insan ticareti konusunda birçok adım atmıştır (Avrupa Birliği, 2018: 13). Çalışmanın bu bölümünde, Arnavutluk'un insan ticaretini önlemeye yönelik politika hedefleri ve bu hedeflerin uygulamada göstermiş oldukları farklılıklar tartışılacaktır. Politika adımındaki değerlendirmelerin akabinde, hukuki olarak ne gibi yaptırımlar uyguladığı doktrinden alıntılar yaparak yasal düzenlemelerin politika hedefleriyle uyumluluğu değerlendirilecektir.

Arnavutluk Hükümeti 1998 yılına kadar insan ticareti ile ilgili her hangi bir hukuki zemine sahip değilken bahsi geçen yılda İçişleri Bakanlığı bünyesinde kurulan İnsan Kaçakçıllı̆ına Karşı Görev Gücü ile bu suça karşı devlet nezdinde ilk adımı atmıştır (Portanova, 2018; Townsend, 2019). Arnavutluk, 2001 yılında insan ticareti suçunu ceza hukuku sistemine alarak devletin eğilimini normatif hale getirmiştir. Birçok ülkenin aksine, bu adım Arnavutluk 2002 yılında BM İnsan Ticareti Protokolü'nü onaylayarak yürürlüğe sokmadan önce atılmıştır(U.S. Department of States, 2002). İnsan Ticareti Protokolü'ne ek olarak Arnavutluk Avrupa Konseyi'nin insan ticaretine karşı kullanılacak araçlarını da 20 Kasım 2006 yılında onaylayarak 9642 sayılı kanun olarak iç hukukunda yürürlüğe sokmuştur (Agolli Nasufi ve Bruci, 2019: 491).

Arnavutluk'ta bu suç ile ilgili olarak 2001 yılına kadar her hangi bir tanımlama yoktur. 1995 tarihli Arnavutluk Ceza Kanununun m.114'ne göre insan ticaretine en yakın suç olarak fuhuş suçu karşımıza çıkmaktadır. 1995-2001 yılları arasında insan ticareti ile ilgili düzenlemeler iki önemli değiş̧iklikle ve eklemeyle 
karşılaştıktan sonra, yeni ceza sisteminin içerisine m.110/a ve m.128/b olarak eklendi. Bu maddelerin ilki yetişkinlerin mağdur oldukları insan ticareti suçunu kapsarken, ikincisi reşit olmayan mağdurlar ile alakalı olarak insan ticaretini suç olarak tanımlamıştır. Bu maddelerin detaylarına bakacak olursak; İnsan Ticareti Protokolüyle aynı doğrultuda tanımlanan insan ticareti suçunun cezası 5 yıldan 15 yıla kadar hapis ve 2 milyon Arnavutluk Lek'inden 5 milyon Lek'e kadar da para cezası olarak belirtilmiştir. Cezayı arttırıcı bir etken olarak suçun organize şekilde işlenmesi halinde ise insan ticareti yapan örgütlere, örgüt yöneticilerine ve bu örgütlere finansal destek sağlayanlara 7 yıldan 15 yıla kadar hapis ve 4 milyon Lek'ten 6 milyon Lek'e kadar para cezasına hükmedilebileceği belirtilmiştir. İnsan ticareti suçu işlenirken diğer suçlarla (fiziksel şiddet ve sağlı̆̆ın kötü etkilenmesine sebep olacak davranışlar) birleşmesi durumunda ise insan ticareti suçunun cezası 15 yıldan az olmamak kaydıyla hapis cezası ve 6 milyon Lek'ten 8 milyon Lek'e kadar para cezası olarak belirtilmiş̧ir. Bu suç sırasında karşılaşılabilecek en ağır senaryo ise ölümle neticelenen insan ticareti suçudur, burada m.110(a) 20 yıldan az olmamak şartıyla hapis cezasına ve 7 milyon Lek'ten 10 milyon Lek'e kadar para cezasına hükmedileceğini vurgulamıştır. Bu doğrultuda bakıldığı zaman insan ticareti ile ilgili uygulanacak cezaların suçu önlemeye ve suçla savaşmaya yönelik bir doğrultu izlerken aynı zamanda mağdurların cezaların ağırlığı sebebiyle korunmasını hedeflemektedir.

Normatif olarak atılan bu adımlarla beraber 2011-2013 yılları arasını kapsayan bir aksiyon planı devreye sokulmuştur. Bu planın içeriği, insan ticareti ile mücadele için hukuki düzenlemelerin, istatistik tutmanın ve bilgilerin takibinin önemini, hizmetleri, farkındalık projelerini ve işbirliklerini altını çizerek vurgulamıştır (Balidemaj, 2019: 1307). Bu adım ile hedeflenen ise Arnavutluk hukuk sisteminin uluslararası hukuk ile uyumunu arttırarak insan ticareti için yeni bir standart ortaya koymaktır. Bu bağlamda, Arnavutluk'un insan ticareti suçunu kriminal hale getirdiğini söylemek mümkündür fakat insan ticareti ile ilgili olarak en temel problemlerden biri ise mağdurların gerçekten mağdur olup olmadıklarını anlayabilmektir. İnsan tacirleri farklı metotlar kullanarak ve farklı istismar yöntemleri ile kişileri insan ticareti mağduru haline getirdikleri için teşhis büyük bir öneme sahiptir (Avrupa Komisyonu, 2013: 2-3; Simich, Goyen, ve Mallozzi, 2014: 11). Bunun nedeni ise mağdurların tekrardan mağdur edilmelerinin önüne geçmek ve ihlal edilen insan haklarının iade edilmesini sağlamaktır. Aksi takdirde, teşhiste bir yanılgı, mağdur olan kişiye ceza verilerek kişi ikincil mağduriyetle yüz yüze bırakmak anlamına gelir. $\mathrm{Bu}$ noktada Arnavutluk kolluk kuvvetlerinin veya ilk müdahale ekiplerinin kurbanların teşhisi için beş bölümden oluşan resmi bir mülakat yöntemi uygulamaktadır. Teşhisin ilk aşaması olarak, mağdurlar veya mağdur olma ihtimali olanlar kendi rızaları ile veya ekiplerin yönlendirmesiyle mülakata alınmaktadır. İkinci adım olarak, kişinin mağdur olup olmadığına karar verilir. Burada, mağdurdan alınan cevapların derlenerek analiz edilmesi şeklinde bir 
prosedür izlenir. Bu değerlendirmelerin ardından üçüncü adım olarak, mağdurun desteğe ve korunmaya ihtiyacının olup olmadığına karar verilir. Kişinin mağdur olduğunun netleştiği ve suç içerisinde yaşadığı mağduriyette derecelendirildikten sonra dördüncü adım olarak mağdurun durumuna en uygun desteğin belirlenerek güvenli bir şekilde destek alması sağlanmaktadır. Bu sürecin son adımında ise tüm bu süreçlerin akabinde mağdur kişinin insan ticareti mağduru olduğu onaylanır (Agolli Nasufi ve Bruci, 2019: 491).

Mağdurların belirlenmesinin ardından hakların iade edilmesi ve destek görme süreçleri ortaya çıkmaktadır. Bu noktada, Arnavutluk'un hukuk sisteminin insan ticareti mağdurlarının haklarını iade etmekle ilgili doğrudan bir düzenlemesinin olmaması mağdurları süreç içerisinde zaman kaybı yaşatarak yeniden belirli ölçüde mağdur etmektedir. Bunun yanında, sivil mahkemelerde insan tacirlerine dava açma hakları saklı tutulmuş ve bu haklar Ceza Muhakemesi Kanunu'nun içerisinde m.61'de düzenlenmiştir. Bunlara rağmen, Arnavutluk'un birçok ülkede olduğu gibi hukuki eksiklikleri nedeniyle problemlerle karşılaşması söz konusudur. Bu problemlerin başında, İnsan Ticareti Protokolü'nün getirmiş olduğu tanımın geniş, açıklayıcı, birçok unsuru kapsayan yapısı uygulamada ve yorumlamada sorunlara neden olmasidır (Kranrattanasuit, 2014: 111). Arnavutluk'un iç hukukunda insan ticareti ile ilgili hükümler olmasına rağmen mağdurların ihlal edilen hakları ile ilgili daha önce de bahsedildiği gibi kolaylaştırıcı bir yol ortaya konmamıştır. Öyle ki, insan ticareti ile ilgili olarak 2006 yılında oluşturulan Ulusal Koordinatörlük, hakların geri verilmesi ve zararların tazmin edilmesi için tacirlerden ele geçirilen mülklerin gelirlerine dayandırılmıştır. 2014-2017 yılları için hazırlanan 'İnsan Ticareti ile Mücadele Stratejisi ve Aksiyon Planı" içerisinde de mağdurların haklarının iade edilmesi, rehabilitasyon süreçlerinin yürütülmesi ve zararlarının tazmin edilmesi yine aynı şarta bağlanmıştır.

Buradan da görüleceği gibi bu süreçte bahsi geçen konularla ilgili yapıcı ve düzenleyici etkin bir adım atılmamıştır. Bir diğer değişle Arnavutluk insan ticareti suçunu normatif olarak suç haline getirmiş fakat mağdurların korunması konusuna yeterince eğilmemiştir (Asllani, 2018: 8). Buna örnek olarak ise, insan ticareti konusunda çok sıkça literatürde görülen bir cümle ile açıklık getirmek önem arz eder. İnsan ticareti mağdurları hem suçun mağduru hem de görgü tanıklarıdırlar (Ward ve Fouladvand, 2018: 139). Bu minvalde, Arnavutluk Ceza Muhakemeleri Kanunu m.316 insan ticareti mağdurlarına özel koruma yöntemleri getirmiştir. Bu yöntemler uzaktan mahkemelere katılmak, ifadeler sırasında ses ve görüntüyü mağdur tanınmayacak şekilde almak olarak belirtilmiştir. Buna ek olarak, mağdurların hukuki yardım almaları noktasında da Arnavutluk Anayasası m.31 doğrultusunda kişilerin savunma hakkı gözetilerek mahkemede vekil atanması konusuna olanak tanınmıştır. Fakat bu durum normal vatandaşlar ile aynı yürütülmeyerek şarta bağlanmıştır. Ceza Kanunu m.61 ve 
62'nin düzenlemelerine göre, bir insan ticareti mağduru avukat tarafindan savunulma hakkına ancak ceza davasına sivil bir müşteki olarak katılması ve insan tacirinden tazminat istediğinde bulunması durumunda sahip olabilmektedir. Hal böyle olsa bile mahkeme mağdura ücretsiz vekil tayinini garanti etmemektedir (Anti-Human Trafficking and Migrant Smuggling Unit, 2010; Balidemaj, 2019: 1311). Başlı başına bu durum bile mağdurların en temel insan haklarından biri olan savunma hakkının tazmin edilmesini gerektirmekte ve yaşamış oldukları mağduriyetin tekrarlandığının (re-victimization) bir göstergesidir.

Arnavutluk'un, hukuki anlamda eksiklikler olsa bile, mağdurların hayata yeniden entegrasyonunu ve ihtiyaç duydukları hizmetleri sağlamak için açtı̆̆ 1 dört adet insan ticareti mağdurlarına özel sığınma evi bulunmaktadır. Bu dört sı ğınma evi İnsan Ticaretine Karşı Sı ğınma Evleri Ulusal Birliği’ni oluşturmaktadır. $\mathrm{Bu}$ birlik hukuki destekten meslek edindirmeye, çocuk mağdurlara destekten uzun süreli konaklama hizmetlerinin teminine kadar birçok konuda mağdurlara destek sunmaktadır. Bu sığınma evleri Birleşik Devletlerin yıllık olarak yayınladığı insan ticareti raporuna göre toplamda 115 mağdura destek hizmeti sağlamıştır (U.S. Department of States, 2020: 69).

\section{Arnavutluk'un İnsan Ticareti ile İlgili Karnesi}

Arnavutluk, Amerika Birleşik Devletleri'nin 2001 yılından bu yana düzenli olarak yayınladığı İnsan Ticareti Raporlarının (ITR) en günceli olan 2020 raporunda Tier 2 ülkeleri arasında gösterilmiştir (U.S. Department of States, 2020: 69). Bunun anlam1, insan ticareti ile ilgili uyulmas1 gereken minimum standartlara uygun davranılması olarak ifade edilmektedir. ${ }^{2}$ Raporların başladığ 1 dönemden bu yana Arnavutluk 2008 ve 2013 y1llarında olmak üzere Tier 2 statüsünde bir adım gerilemiş ve izleme listesine girmiştir. 2008 yılındaki gerilemenin sebebi 2007 yılında, özellikle de mağdurların korunması alanında, insan ticareti ile mücadele çabalarının arttı̆̆ına dair kanıt sunamaması olarak ifade edilmişken, 2013 raporlama döneminde hükümet, bir önceki raporlama

$2 \mathrm{Bu}$ standartlar 2000 yılında ortaya konan İnsan Ticareti Mağdurlarını Koruma Sözleşmesi 108. Bölümünde ortaya konulmuş ve İnsan Ticaretini Ortadan Kaldırmak İçin Uyulması Gereken Minimum Standartlar olarak adlandırılmıştır. Buna göre: 1) Ülke hükümeti, insan ticareti biçimlerini yasaklamalı ve bu tür insan ticareti eylemlerini cezalandırmalıdır; 2) Güç kullanımı, hile ve baskı içeren insan ticaretinde veya anlamlı bir rıza gösteremeyen çocukların cinsel istismar için ticaretinin yapılmasında veya tecavüz ve kaçırma içeren ya da ölümle sonuçlanan insan ticareti suçlarında devletler suçun ağırlığıyla orantılı cezalar vermelidir.; 3) Kişilerin ağır bir insan ticareti eylemi yapması durumunda, ülke hükümeti caydırmaya yetecek, sıkı ve suçun iğrenç doğasını yeterince yansıtan cezalar vermelidir; 4) Ülke hükümeti, insan ticaretinin ciddi biçimlerini ortadan kaldırmak için ciddi ve sürekli çaba sarf etmelidir. 
döneminde insan ticaretine yönelik çabaların arttı̆̆ına dair kanıt gösteremedi ifadesi kullanılmıştır (U.S. Department of States, 2008: 54-55; U.S. Department of States, 2013: 67-69). Buradan da anlaş1labileceği gibi ilk gerileme temelde mağdurların korunmasına yönelik yetersiz çaba iken, ikinci gerilemede ise insan ticareti ile topyekün mücadelede ortaya çıkan motivasyon kaybıdır. Genel itibariyle Arnavutluk insan ticareti konusunda ortaya konan minimum standartlara tam anlamıyla uymuyor olsa bile bu yönde çaba gösteren bir ülke olarak karşımıza çıkmaktadır.

Arnavutluk Hükümeti, 2016 yılında mağdur kadınların ve kız çocuklarının ekonomik durumları, barınmaları, eğitimleri, sosyal desteklerden faydalanmaları ve hayata yeniden entegre olmaları için "Mağdur Kadın ve Kız Çocuklarının Sosyal ve Ekonomik Entegrasyonuna Dair Eylem Planı" hazırlamıştır (Gjebrea, 2016: 7). Bu eylem planının hemen akabinde, İçişleri Bakanlığı ve Ulusal İnsan Ticareti Koordinasyon Bürosu Uluslararası Göç Örgütü ile beraber ülkenin organize suçlar ile ilgili stratejileri ile doğru orantılı bir eylem planı hazırlı̆̆ına girişmiştir (Birleşik Krallık İç İşleri Bakanlığı, 2018b: 35). Ocak 2016’da kurulan Mağdur Yardım Bürosu özellikle reşit olmayan, engeli bulunan, şiddet gören ve cinsel istismara maruz kalan insan ticareti kurbanlarına destek vermek için kurulmuştur. Birleşmiş Milletler bu konuda Arnavutluk'un bu adımını desteklediğini beyan etmiştir (UN Committee, 2016: 32-33). Bu adımlar sadece devletin çabaları ile sınırlı kalmamış ve halktan da bir karşılık görmek için devlet eliyle ve uluslararası örgütlerin destekleriyle projeler organize edilmiştir. $\mathrm{Bu}$ bağlamda ilk dikkat çeken farkındalık projesi Ekim 2017-Mart 2018 döneminde insanları göçe veya insan ticaretine iten sebeplerden olan ekonomi, sağlık ve eğitim temelli sorunları hafifletmeyi hedefleyen ve Arnavutluk'un 12 bölgesinde aynı anda başlatılan ve Uluslararası Göç Örgütünün desteklediği "Şansı Seç, Düzensiz Göçü Değil" projesidir (IOM, 2017). Bunun yanı sıra, insan ticaretini önlemek adına Farklı ve Eşit adlı sivil toplum kuruluşu ile çalışan ve Tiran Belediyesi çalışanı olan bir sosyal hizmetler yetkilisi okullara ziyaretler düzenleyerek gençleri bilgilendirmiştir (Birleşik Krallık İç İşleri Bakanlığı, 2018b: 35). Son beş y1llık ilerlemeler doğrultusunda hem önlemeye yönelik hem de mücadeleye yönelik ulusal ve uluslararası enstrümanlar kullanılmıştır. Fakat bu dönemi daha iyi değerlendirmek için yine Birleşik Krallığın 2020 yılında yayınlamış olduğu değerlendirme raporuna bakarak 2018 yılından Haziran 2020'ye kadar neler yapıldığına bakmak önemlidir. Bu dönemde Arnavutluk, insan ticaretini önlemeye ağırlık vermiş ve organize suçlar, yasa dışı ticaret ve terörizm ile ilgili düzenlemeler yaparak Avrupa Konseyi'nin dikkatini çekmiştir (Birleşik Krallık İç İşleri Bakanlığı, 2020: 32). İnsan Ticaretine Karşı Ulusal Eylem Planı (2018-2020) kapsamında toplumsal farkındalık oluşturmak için çaba sarf etmiş ve çocuk mağdurlar için teşhis aşamasından başlayarak süreci daha hassas yürütmek noktasında çaba göstermiştir (U.S. Department of Labor, 2018). 
Yukarıda bahsedilen tüm çabalara rağmen özellikle cinsel istismar amacıyla yapılan insan ticaretinde oluşan talebi ortadan kaldırmaya yönelik bir adım atmaması, Arnavutluk'un çabalarını gölgede bırakmaktadır (Birleşik Krallık İç İşleri Bakanlığı, 2020: 33). Gerek ulusal gerekse uluslararası anlamda atılan adımlar değerlendirilmiştir. Bu doğrultuda Tier 2 statüsünde olan Arnavutluk'un insan ticareti ile mücadelenin asgari şartlarını sağlayabilmesi için gereken adımlara hem önceki çabaları iyileştiren hem de gelecekte atılacak adımları sağlamlaştıracak nitelikteki unsurlar 2020 yılında Birleşik Devletler tarafindan ortaya konmuştur. Buna göre Arnavutluk şu konular üzerinde durmalıdır: soruşturma, yargılama ve ceza süreçlerinde değişiklik, mağdur tespitinde hassasiyet, süreçlere dahil olan kolluk kuvvetlerinin bilgilendirilmesi, başka iş kollarının altında yürütülen insan ticaretini fark edebilmek için kalifiye ve farkındalık sahibi elemanların yetiştirilmesi, mağdurlar için sığınma evleri kurmak ve finanse etmek, reşit olmayan mağdurların haklarının daha dikkatli ve özenli bir şekilde tazmin edilmesi, ve tüm süreç içerisinde mağdur merkezli bir yaklaşım benimsenmesi (U.S. Department of States, 2020: 68).

İnsan ticareti ile ilgili asgari şartları sağlamak bakımından önem arz eden bu noktalar da gösteriyor ki insan ticaretini kanunlarda suç haline getirmek yeterince mağdur merkezli adımlar atılmadıkça Arnavutluk'u sadece yerinde saydırmaktadır. Bu önerileri daha iyi yorumlayabilmek için Arnavutluk’un aday ülke statüsünde bulunduğu Avrupa Birliği'nin ülke hakkındaki en güncel raporlarını inceleyip bir durum değerlendirmesi yapmak hem sorunlar hakkında geniş bir bakış açısı sağlayacak hem de uluslararası bir yaklaşımın iç dinamikleri nasıl etkilediğini gösterecektir. Adaylık yolundaki Arnavutluk'un yıllık ilerlemelerini değerlendiren 2019 raporu Adalet, Özgürlük ve Güvenlik başlı̆̆ 1 altında insan ticaretine yer vermiştir. Rapora göre çocuklar ve kadınlar hem ülke içinde hem de Avrupa Birliği içerisinde insan ticaretine konu edilmektedir. Bu bağlamda, rapor özellikle refakatsiz seyahat eden çocuklara ve insan ticareti mağduru çocuklara özen gösterilmesi gerektiğini vurgulamıştır (Avrupa Birliği, 2019: 36). İnsan ticareti davalarına da değinen rapor bu noktada 2020 y1lında yayınlanan raporla tutarlı bilgiler vererek 2017 y1lında insan ticareti ile ilgili 30 adet dava olduğunu bu sayının 2018 yılında 21 davaya düştüğünü söylemiş fakat davaların yavaş ilerlediğini vurgulamak için 2017 yılında sadece 9 davanın, 2018 yılında da 3 davanın sonuçlandığını söylemiştir (Avrupa Birliği, 2019: 35; Avrupa Birliği, 2020: 6). Bu noktada 2019 raporunu iki kısımda incelemek gerekmektedir. Bunun nedeni, Avrupa Komisyonu raporlama döneminde karşılaşılan olumlu adımları, olumsuzlukları ve yetersiz gördügü noktalar içinde önerilerini ortaya koymuştur. Bu bağlamda, Komisyon, raporlama döneminde insan ticareti mağdurlarına destek sunan sığınma evlerinin fonsuz kaldığını ve hükümetin mağdur merkezli soruşturma ve yargılama yapamadığını söyleyerek en temel eleştirilerini beyan etmiştir. Bu eleştirilere ek olarak Arnavutluk'un Ceza Muhakemeleri Hukuku'nda insan ticareti mağdurlarının haklarını 
koruyacak ve hali hazırda ihlal edilmiş olan haklarını tazmin edecek bir yapılandırmanın olmamasını da eleştirmiştir (Avrupa Birliği, 2019: 35). Bu eleştirilerle beraber Komisyon ülkeye insan ticareti ile daha iyi mücadele edecek ve mağdurların korunmasını sağlayacak yöntemlerle ilgili bilgilendirmiştir. Önerilerden ilki, insan ticareti suçunun sınıraşan organize suç kimliğine vurgu yaparak bu suçun diğer organize suç faaliyetleri ile olan beraberliğini göstermiş ve insan ticareti ile ilgili soruşturmaların bir ayağının da finansal boyutta bir soruşturma olması gerektiğine vurgu yapmıştır. Bu minvalde 2019 raporunun son önerisine geçmeden 2020 yılı raporunda Komisyon, bir önceki yıl Avrupa Birliği'ndeki uyuşturucu ticaretine karşı 3 yıllık bir takibatın ardından neticelendirilen operasyonda uyuşturucu ticareti yapan organize suç örgütlerinin aynı zamanda insan ticareti de yaptıklarının tespit edildiğini vurgulamıştır (Avrupa Birliği, 2020: 5). Komisyon, 2019 yılındaki raporunda, özellikle mağdur merkezli bir adalet sistemi oluşturmak ve suçun önlenmesini sağlayabilmek için Arnavutluk’a ceza adaleti sisteminin kuvvetlendirilmesi yönünde öneride bulunmuştur (Avrupa Birliği, 2019: 35).

Çalışmanın bu bölümünde Arnavutluk'un durumunu değerlendirirken kullanılan üç raporun ortak olarak altını çizdiği konulara baktığımızda net bir şekilde çocuk mağdurlara hassasiyet gösterilmesi gerektiği ve hukuk sisteminin daha mağdur merkezli bir şekilde yeniden tasarlanması gerektiğini görmekteyiz. Bunun dışında ortak öneri noktalarının, bir diğeri ise, insan ticaretinin organize suçlar ile alakalı karakteristik özelliklerinin gözetilmesi gerektiği ve diğer suçlarla ilgili soruşturmalar yürütülürken bu suça da dikkat edilmesi hususu özellikle vurgulanmıştır. Üç raporunda vurguladığı mağdur merkezli bir sistem dizaynının belki de en net yansıdığı nokta, mağdurlara ve muhtemel mağdurlara sağlıktan eğitime, hukuki danışmanlıktan ekonomik desteğe kadar birçok konuda yardımcı olan sığınma evlerinin hükümet tarafindan daha fazla desteklenmesi vurgulanmıştır.

\section{SONUÇ}

Çalışma, Arnavutluk'un insan ticareti ile olan ilişkisini ve bu iliş̧inin neticesinde ortaya çıkan hukuki ve idari çıktıları uluslararası nitelikteki belgelerle sistematik bir şekilde incelemiş ve kritik etmiştir. Çalışma iki temel bölümden oluşmuş ve bu bölümlerin ilki konu ile ilgili terminolojik ve coğrafi bilgileri ortaya koymuştur. İkinci bölümde ise Arnavutluk'un insan ticaretine karşı atmış olduğu adımlar değerlendirilmiş ve bu değerlendirme sonucunda çıkan olumlu ve olumsuz yönler uluslararası raporlarla yorumlanmıştır.

Konu ile ilgili en temelde sorulması gereken sorulardan olan "insan ticareti nedir?" ve "bu suçun mağdurları kimlerdir?" sorularına literatür yardımıyla cevap verilmiştir. İnsanlar, herhangi bir cinsiyet, yaş, 1rk, bölge ve ülke ayrımı 
gözetilmeksizin bu suçun mağduru olabilmektedir. Nitekim, dünyada farklı coğrafyalarında insan tacirleri birbirinden farklı istismar amaçlı bu ticareti yürütmektedir. Buna ek olarak, insan ticareti sınıraşan bir karakteristik özelliğe sahip gibi görünse de ülke sınırları içinde de yapılan bir suç olarak günümüzde 25 milyon insanın mağdur olduğu bir suç olarak kayda geçmiştir.

Ülkelerin veya coğrafyaların jeopolitik konumları neticesinde karşılaştıkları savaş ve kıtlık gibi olgular, göç rotalarına ve talebe olan yakınlık konuları belli bir bölgede bu suça olan katılımı arttırırken, insan tacirlerine kurban bulma olanağı da sağlamıştır. Günümüzde organize suç örgütlerinin daha ön plana çıktığı bu ticaret, bölgeler bazında incelendiğinde farklılık göstermektedir. Balkan coğrafyasına baktığımızda Batı Avrupa'ya geçiş için hali hazırda kullanılan bir rota üzerinde olması, gerek Suriye İç Savaşı nedeniyle 2011 yılında doğan göç akınlarında ön plana çıkması gerekse Kuzey Afrika'dan deniz yoluyla ulaşılabilir olması bu bölgeyi son dönemde insan ticareti için de kritik hale getirmiştir. $\mathrm{Bu}$ duruma ek olarak, Balkan ülkelerinde artan organize suç yapılanmaları göçmen kaçakçılığı, tütün ve tütün ürünleri ticareti, uyuşturucu ve silah ticareti gibi yasa dişı faaliyetlere ek olarak insan ticaretini de gelir elde etmek amacıyla yoğun bir şekilde kullanmaya başlamışlardır.

Konjonktürel değişiklikler ve değiştirilemeyecek olan coğrafi konum gibi bir gerçeklik arasında Balkan ülkelerinden Arnavutluk'a baktığımızda da insan ticareti konusunun hem hukuki hem de politik bir değerlendirme altında olduğu görülmektedir. Bu bağlamda, Arnavutluk'un 2001 yılından sonra hukuki anlamda bir ivme yakaladığı yadsınamaz bir gerçek olarak ortadadır. Ceza Hukuku içerisine alınan insan ticareti bu vasıtayla suç olarak tanımlanmıştır. Akabinde Birleşmiş Milletler İnsan Ticareti Protokolü'ne taraf olan Arnavutluk bu konuda uluslararası düzeyde bir adım atmıştır. Sonraları ise hem Protokolün gereklerini yerine getirmek hem de Avrupa Birliği üyelik müzakereleri çerçevesinde Arnavutluk, insan ticaretini önlemeye ve mağdurların korunmasına yönelik birçok adım atmıştır. Bu adımların başında mağdurlar için sığınma evleri açmak, farkındalık kampanyaları yapmak ve uluslararası düzeyde sağlanan işbirliği gelmektedir. Birleşik Devletler'in yıllık insan ticareti raporlarında istikrarlı bir tablo çizen Arnavutluk konu ile ilgi asgari şartları sağlamak bakımından çaba gösteren ülkelerden biri olarak gösterilmektedir. Fakat bu çaba yanında, hem AB raporlarında hem de Birleşik Devletlerin raporlarında bazı konularda ciddi uyarılar yer almış ve bu eksiklikleri gidermek adına öneriler sunulmuştur. Arnavutluk'un insan ticareti ile mücadelesinde yetersiz kaldığ 1 noktaların başında ülkenin Ceza Hukuku Sisteminin mağdurları merkeze alan ve onları korumaya yönelik adımlarının yetersiz olduğu konusu gelmektedir. Ülke, sistem olarak konuyu suç olarak görmekte fakat insan ticareti ile mücadelenin en önemli adımlarından biri olan korumayı geri plana atmaktadır. Bu çıkarıma ulaşmakta raporlar özellikle sığınma evlerinin yeterince fon alamaması 
konusunu, ceza muhakemeleri sisteminde mağdurların ihlal edilen haklarını tazmine yönelik atacakları adımların kolaylaştırılmaması konuları gelmektedir. Bir diğer eksiklik ise insan ticareti konusunun tek taraflı bir suç olmama ihtimalinin Arnavutluk tarafından göz ardı edilmesi olarak gündeme gelmektedir. Öyle ki, hemen hemen tüm Avrupa'yı etkileyen uyuşturucu ticareti ile ilgili yapılan büyük ölçekli bir operasyonda organize suç örgütünün insan ticareti de yaptığı gerçeği vurgulanmıştır. Bu konularla ilgili olarak yapılan öneriler ise özetle, sığınma evlerine maddi destek, mağdur merkezli bir süreç (saptamadan mağdurların yeniden hayata uyumunu sağlamaya kadar uzanan) organize etmek. Ek olarak, başta kadın ve çocuk mağdurlara süreçte daha hassas davranarak onların süreç içinde yeniden mağdur olmalarına engel olmak, organize suç örgütlerinin her iştiraklerine ulaşabilmek adına özellikle finansal anlamda yürütülecek bir soruşturma ve kovuşturma süreci tasarlamak.

\section{KAYNAKLAR}

Agolli Nasufi, I. and Bruci, A. (2019). Government responses to the survivors of trafficking in human beings: a study of Albania. World Academy of Science, Engineering and Technology International Journal of Law and Political Sciences, 13(4), 489-499.

Anti-Human Trafficking and Migrant Smuggling Unit. (2010). Smuggling of migrants-a global review and annotated bibliography of recent publications. UNODC.

Antunes, S. and Camisao, I. (2017). Realism. Içinde S. McGlinchey, R. Walters, and C. Scheinpflug (Ed.), International relations theory (ss. 15-22). EInternational Relations Publishing.

Arapi, L. (2017, Kasim 20). Syrian refugees find a home in Albania. InfoMigrants. https://www.infomigrants.net/en/post/6159/syrianrefugees-find-a-home-in-albania

Arsovska, J. (2019). The rise of Balkan organized crime. İçinde M. Natarajan (Ed.), International and transnational crime and justice (2. bs, ss. 198203). Cambridge University Press. https://doi.org/10.1017/9781108597296.033

Arsovska, J. and Basha, D. (2013). Globalizing the Western Balkans: Transnational crime, fundamental Islam and unholy alliances. Études caribéennes, 22. https://doi.org/10.4000/etudescaribeennes.5871

Asllani, D. N. (2018). The civil compensation of criminal acts in Albania. Tort Law, 5, 1-9. 
Avrupa Birliği. (2018). Data collection on trafficking in human beings in the EU. Publications Office of the European Union. https://ec.europa.eu/homeaffairs/sites/homeaffairs/files/what-we-do/policies/european-agendasecurity/20181204_data-collection-study.pdf

Avrupa Birliği. (2019). Albania 2019 report (Commission Staff Working Document $\quad$ COM(2019) $260 \quad$ final). Avrupa Komisyonu. https://ec.europa.eu/neighbourhoodenlargement/sites/near/files/20190529-albania-report.pdf

Avrupa Birliği. (2020). Update on the Republic of Albania (Commission Staff Working Document SWD(2020) 46 final). Avrupa Komisyonu. https://ec.europa.eu/neighbourhoodenlargement/sites/near/files/update-on-the-republic-of-albania.pdf

Avrupa Komisyonu. (2013). Guidelines for the identification of victims of trafficking in human beings. https://ec.europa.eu/antitrafficking/sites/antitrafficking/files/guidelines_on_identification_of_vi ctims_1.pdf

Avrupa Konseyi. (2004). Organised crime situation report 2004. Avrupa Konseyi. https://www.coe.int/t/dg1/legalcooperation/economiccrime/or ganisedcrime/Organised\%20Crime\%20Situation\%20Report\%202004.p df

Avrupa Konseyi. (2006). Crime situation report on economic and organized crime in South-eastern Europe (PCTC(2006)9). https://www.esiweb.org/pdf/montenegro_COESEE\%20org\%20crime-2006.pdf

Balc1, M. ve Göcen, C. E. (2019, Nisan 26-28). Avrupa Birliği'de artan zorluklar: göçmen krizi ve ırkçılık [Sözlü Sunum]. Sosyal Bilimler Kongresi, Elazığ, Türkiye. https://www.researchgate.net/publication/337161432_AVRUPA_BIRLI GI'NDE_ARTAN_ZORLUKLAR_GOCMEN_KRIZI_VE_IRKCILIK

Balidemaj, A. (2019). Human rights legislation in Albania: The case of human trafficking. The International Journal of Human Rights, 23(8), 13001316. https://doi.org/10.1080/13642987.2019.1601083

Balkans Route. (2020). Refugees in Towns. https://www.refugeesintowns.org/balkans-route 
Bechev, D. (2020, May1s 1). Europe's refugee crisis and the Balkans. Al Sharq Think Tank. https://research.sharqforum.org/2016/06/08/europesrefugee-crisis-and-the-balkans/

Binder, D. (2020, May1s 8). 269. Organized crime in the Balkans | Wilson Center. https://www.wilsoncenter.org/publication/269-organized-crimethe-balkans

Birleşik Krallık İç İşleri Bakanlığı. (2018a). Country policy and information note Albania: people trafficking. https://www.refworld.org/docid/5b3b34557.html

Birleşik Krallık İç İşleri Bakanlığı. (2018b). Report of a home office fact-finding mission

Albania. https://assets.publishing.service.gov.uk/government/uploads/sy stem/uploads/attachment_data/file/681071/Home_Office_FFM_Report_ -_Albania.pdf

Birleşik Krallık İç İşleri Bakanlığı. (2020). Country policy and information note Albania: trafficking of women for sexual exploitation. https://assets.publishing.service.gov.uk/government/uploa ds/system/uploads/attachment_data/file/896134/Albania__Trafficking_-_CPIN_-_v9.0_June_2020_.pdf

Bregu, M. (2019). The effects of the migration crisis in Albania: The Syrian Refugee Case. 2(18), 64-74.

Brunovskis, A. and Surtees, R. (2019). Identifying trafficked migrants and refugees along the Balkan route. Exploring the boundaries of exploitation, vulnerability and risk. Crime, Law and Social Change, 72(1), 73-86. https://doi.org/10.1007/s10611-019-09842-9

CATW-Asia Pacific. (1996). Trafficking in women and prostitution in the Asia Pacific. Coalition Against Trafficking in Women-Asia Pacific.

Centre for Women and Children Studies. (1997). The Bangladeshi-Pakistan and Nepal-India Estimates. Fact-Finding National Workshop on Trafficking inWomen and Children, Bangladeş.

Daguno, I. (1998). Migration and trafficking of Filipinowomen for prostitution. İçinde L. C. Amilbangsa \& Women's Education, Development, Productivity and Research Organization (Philippines) (Eds.), Halfway through the circle: The lives of eight Filipino women survivors of 
prostitution and trafficking (ss. 1-16). Women's Education, Development, Productivity and Research Organization.

Danforth, L., Crampton, R. and Allcock, J. (2016). Balkans | Definition, map, countries, \& facts. Encyclopedia Britannica. https://www.britannica.com/place/Balkans

D’Cunha, J. (2002). Trafficking in persons: A gender and rights perspective. Seminar on Promoting Gender Equality to Combat Trafficking in Women and Children. https://www.un.org/womenwatch/daw/egm/trafficking2002/re ports/EP-DCunha.PDF

Dottridge, M. and Machel, G. (2004). Kids as commodities? Child trafficking and what to do about it. International Federation Terre des Hommes.

Europol. (2019). EU drug markets report. Publications Office of the European Union. https://www.emcdda.europa.eu/system/files/publications/12078/ 20192630_TD0319332ENN_PDF.pdf

Felsen, D. and Kalaitzidis, A. (2005). A historical overview of transnational crime. İçinde P. Reichell (Ed.), Handbook of transnational crime \& justice (ss. 3-19). Sage Publication.

Frontex. (2018). Western Balkan route. https://frontex.europa.eu/along-euborders/migratory-routes/western-balkan-route/

Frontex. (2019). Albania and FRONTEX launch the first ever joint operation outside EU [Text]. EEAS - European External Action Service - European Commission. https://eeas.europa.eu/headquarters/headquartershomepage/62894/albania-and-frontex-launch-first-ever-joint-operationoutside-eu_en

Gibbons, J. (Ed.). (2015). Drug money: the illicit proceeds of opiates trafficked on the Balkan route. United Nations Office on Drugs and Crime. https://www.unodc.org/documents/rpanc/Publications/other_pub lications/Balkan_route_web.pdf

Gjebrea, L. (2016). National action plan for the socio-economic re-integration of women and girls victims of trafficking in the Republic of Albania. Pegi. https://mb.gov.al/wp-content/uploads/2018/01/16-04-19-04-2808National_action_plan_for_the_socio-economic_reintegration_of_women_and_girls_victims_of_trafficking_in_the_Rep_o f_Albania.pdf 
Global Initiative against Transnational Organized Crime. (2017). Crooked kaleidoscope organized crime in the Balkans. Global Initiative against Transnational Organized Crime. https://globalinitiative.net/wpcontent/uploads/2017/07/OC_balkans.pdf

Global Initiative Against Transnational Organized Crime. (2019). Hotspots of organized crime in the western Balkans: Local vulnerabilities in a regional context. https://globalinitiative.net/wpcontent/uploads/2019/05/Hotspots-Report-English-13Jun1110-Web.pdf

İnsan Ticaretinin, Özellikle Kadın ve Çocuk Ticaretinin Önlenmesi, Ortadan Kaldırılması ve Cezalandırılmasına İlişkin Protokol, 48042003 (2003). https://www.tbmm.gov.tr/kanunlar/k4800.html

Instat Albania. (2005, Mart 21). Albanian emigration 1989-2001. Conference of European Statisticians, http://www.instat.gov.al/media/4386/migration-in-albania-2001.pdf

Interpol. (2019). Human trafficking. https://www.interpol.int/en/Crimes/Humantrafficking

IOM. (1998). Analysis of data and statistical resources available in the EU member States on trafficking in humans, particularly in women and children for purposes of sexual exploitation. IOM.

IOM. (2017). Choose opportunities, not irregular migration!. http://www.mb.gov.al/wpcontent/uploads/2018/01/Choose_opportunities_not_irregular_migratio n.pdf

Kranrattanasuit, N. (2014). ASEAN and human trafficking: Case studies of Cambodia, Thailand and Vietnam. Brill Nijhoff.

Krasniqi, K. (2016). Organized crime in the Balkans. European Scientific Journal, ESJ, 12(19), 204220. https://doi.org/10.19044/esj.2016.v12n19p204

Limoncelli, S. A. (2009). Human trafficking: globalization, exploitation, and transnational sociology. Sociology Compass, 3(1), 7291. https://doi.org/10.1111/j.1751-9020.2008.00178.x

Lotspeich, R. (1995). Crime in the transition economies. Europe-Asia Studies, 47(4), 555-589. 
Lupsha, P. (1995). Transnational organized crime versus the nationstate. Transnational organized crime, 2(1), 21-48.

Nadelmann, E. A. (2010). Cops across borders: The internationalization of U.S. criminal law enforcement. Pennsylvania State University Press.

O’Neill, A. R. (2000). International trafficking in women to the United States: A contemporary manifestation of slavery and organized crime [CIA Brifingi]. CIA. https://www.cia.gov/library/center-for-the-study-ofintelligence/csi-publications/books-and-monographs/trafficking.pdf

Orlova, A. and Moore, J. (2005). Umbrellas or building blocks: Defining international terrorism and transnational organized crime in international law. Houston Journal of International Law, 27(2), 267-310.

Portanova, M. (2018). Mafia and organized crime in Europe. Il Fatto Quotidiano. https://www.ilfattoquotidiano.it/longform/mafia-andorganized-crime-in-europe/map/

Raymond, J. G. (2002). The new UN trafficking protocol. Women's Studies International Forum, 25(5), 491-502. https://doi.org/10.1016/S02775395(02)00320-5

Rosenau, J.N. (1995). Governance in the twenty-first Century. Global Governance, 1(1), 13-43.

Sınıraşan Örgütlü Suçlara Karşı Birleşmiş Milletler Sözleşmesi, 4800 (2003). https://www.tbmm.gov.tr/kanunlar/k4804.html

Simich, L., Goyen, L. and Mallozzi, K. (2014). Improving human trafficking victim identification - validation and dissemination of a screening tool (NCJ

246712). https://www.ncjrs.gov/pdffiles1/nij/grants/246712.pdf

Sironi, D. F. (2014, Aralık 2). Gli immigrati rendono più della droga la mafia nera nel business accoglienza. l'Espresso. http://espresso.repubblica.it/inchieste/2014/12/02/news/gliimmigrati-rendono-piu-della-droga-la-mafia-fascista-nel-businessaccoglienza-1.190479

Thomas, D. Q., Jones, S., Asia Watch Committee (U.S.), \& Women's Rights Project (Human Rights Watch) (Eds.). (1993). A Modern form of slavery: Trafficking of Burmese women and girls into brothels in Thailand. Human Rights Watch. 
Townsend, M. (2019, Ocak 13). Kings of cocaine: how the Albanian mafia seized control of the UK drugs trade. The Guardian. https://www.theguardian.com/world/2019/jan/13/kings-ofcocaine-albanian-mafia-uk-drugs-crime

UN Committee. (2016). Consideration of reports submitted by states parties under article 73 of the Convention Second periodic reports of States parties due in 2015 Albania (CMW/C/ALB/2). https://www.ecoi.net/en/file/local/1399380/ 1930_1494418572_g1700962.pdf

UNHCR. (2019). Albania. UNHRC. https://www.unhcr.org/see/wpcontent/uploads/sites/57/2019/03/Fact-Sheet-UNHCR-AlbaniaUpdated-31-January-2019.pdf

UNHRC. (2007). Estimate of refugees and displaced persons still seeking solutions in South-Eastern Europe. UNHRC.

UNODC. (2008). Crime and its impact on the Balkans. https://www.unodc.org/documents/data-andanalysis/Balkan_study.pdf

UNODC. (2009). Global report on trafficking in persons. https://www.unodc.org/documents/humantrafficking/Global_Report_on_TIP.pdf

UNODC. (2011). Transnational organized crime fact sheet: smuggling of migrants-the harsh search for $a$ better life. UNODC. https://www.unodc.org/documents/toc/factsheets/TOC12_fs_ migrantsmuggling_EN_Plain.pdf

UNODC. (2012). Global report on trafficking in persons, 2012. United Nations Office on Drugs and Crime.

UNODC. (2014). Global report on trafficking in persons, 2014. United Nations Publication.

UNODC. (2017). Global report on trafficking in persons 2016. United Nations Pubns.

UNODC. (2018). Global report on trafficking in persons in the context of armed conflict 2018. United Nations publication. 
U.S. Department of States. (2002). IIIa. Country narratives_countries A through G. U.S. Department of State. //20092017.state.gov/j/tip/rls/tiprpt/2002/10679.htm

U.S. Department of States. (2008). Trafficking in persons report 2008. https://2009-2017.state.gov/documents/organization/105656.pdf

U.S. Department of States. (2013). Trafficking in persons report 2013. https://2009-2017.state.gov/documents/organization/210738.pdf

U.S. Department of States. (2019). Trafficking in persons report 2019. https://www.state.gov/wp-content/uploads/2019/06/2019Trafficking-in-Persons-Report.pdf

U.S. Department of States. (2020). Traffickin in persons report 20th edition. https://www.state.gov/wp-content/uploads/2020/06/2020-TIPReport-Complete-062420-FINAL.pdf

U.S. Department of Labor. (2018). Child labor and forced labor reports. https://www.dol.gov/agencies/ilab/resources/reports/childlabor/albania

U.S. Department of States. (2006). Trafficking in persons report 2006. https://2009-2017.state.gov/documents/organization/66086.pdf

Vlasis, D. (2002). The UN convention against transnational organized crime. İçinde M. Berdal and M. Serrano (Ed.), Transnational organized crime and international security: Business as usual? (ss. 83-94). Lynne Rienner Pub.

Ward, T. and Fouladvand, S. (2018). Human trafficking, victims' rights and fair trials. The Journal of Criminal Law,82(2), 138155. https://doi.org/10.1177/0022018318761680

Yıldız, F. ve Dikmen Yıldız, P. (2020). Ege Denizi'nde Uyuşturucu Ticareti ve Güvenlik: Uyuşturucu ve Psikotrop Maddelerin Kaçakçılığına Karşı BM Sözleşmesi (Viyana Konvansiyonu). H. Çomak, B. Ş. Şeker, ve D. Ioannidis (Ed.), Ege Jeopolitiği (ss. 1651-1666). Nobel Akademik Yayınc1lık. 